\title{
An Augmented GRavity MOdel of South Africa's EXPORTS OF MOTOR VEHICLES, PARTS AND ACCESSORIES
}

\author{
Moses Muse Sichei
}

The Investment and Trade Policy Centre, Department of Economics, University of Pretoria Jean Luc Erero

The Department of Trade and Industry

Tewodros Gebreselasie

The Investment and Trade Policy Centre, Department of Economics, University of Pretoria

\section{Abstract}

The study applies an "augmented" gravity model to South Africa's exports of motor vehicles, parts and accessories to 71 countries over the period 1994 to 2004. A static panel data model is specified and estimated. Several conclusions are drawn from the study. First, a number of variables, namely, importer income, distance, level of import tariffs, government effectiveness, regulatory quality, use of right-hand drive vehicles are important determinants of bilateral trade flows for motor vehicles, parts and accessories. Second, solving the gravity model deterministically, we show that export potential exists in a number of countries like Malawi, Zambia, Kenya and Malaysia. A number of barriers hinder the members of the National Association of Automobile Manufacturers of South Africa (NAAMSA) from exploiting these export markets. These include very high import tariffs, lack of South Africa's diplomatic mission in the trading partner and the uncertainty regarding what happens at the expiry of the Motor Industry Development Programme (MIDP) in 2012. Finally, the export potential identified by the gravity model should be regarded only as an indication since it is sensitive to the model specification and sample of countries.

Key words: Gravity equation, MIDP, export potential, motor vehicles, parts and accessories, panel data

JEL E33, E52

\section{1}

\section{Introduction}

South Africa's automotive industry, which includes manufacturing, distributing and servicing of vehicles and components, contributes about 7 per cent to the gross domestic product (GDP). In 2005, it employed slightly more than 300000 workers in manufacturing vehicle and automotive components, the tyre industry and distribution and servicing in the motor trade (Table 2). South Africa is ranked 19th in the world in vehicle production, accounting for about 0.7 per cent of the world's vehicle output in 2004 (NAAMSA, 2005). Vehicle production is the second largest industry in South Africa's manufacturing sector, and one of the fastest growing. The contribution of exports of motor vehicle parts and accessories and other transport equipment to South Africa's merchandise exports to the rest of the world grew from 2.8 per cent in 1994 to 9.2 per cent in 2004 .

South Africa's car assembly plants emerged during the 1920s and aimed at mainly servicing the needs of the local market. As the demand grew, the motor industry developed very small plants producing at very high unit costs. Cars were mainly assembled locally from imported components with about 20 per cent local content. During this period, the industrial policy was built around import substitution with high import tariffs. 
South Africa's automotive industry has experienced major policy reforms over the last four decades, which were aimed at improving competitiveness, increasing domestic value addition and promoting exports. During the period 1961-95 automotive manufacturers were obliged to observe local content requirements, which led to the emergence of the Original Equipment Manufacturers (OEM). However, in spite of the reforms, the pre-1995 automotive industry was characterised by many small assembly plants producing too many models at economically low volumes (NAAMSA, 2005). The dissatisfaction with the earlier reforms led to the introduction of the Motor Industry Development Programme (MIDP) in 1995, which complied with the General Agreement on Trade and Tariffs (GATT) and the World Trade Organisation (WTO).

The structural changes have led to a significant increase in exports of automotive products. Vehicle exports as a percentage of domestic production increased from 4 per cent in 1995 to 27 per cent in 2005 (Table 2). Exports of component parts increased from 12.6 billion rands in 2000 to 21.7 billion rands in 2004 (Table 3). The main export destinations are, among others, Germany, the United Kingdom, United States, Japan and Australia (Table 3). According to NAAMSA (2005), components accounted for 55 per cent while build-up vehicles contributed 45 per cent of the total automotive export revenues in 2004.

Black (2003) shows that rapid export expansion, considerable foreign investment and productivity improvements in the motor industry have been strongly influenced by the MIDP programme. As pointed out by Franse (2006), export expansion remains crucial to the future sustainability of South Africa's automotive industry since the size of the domestic market is relatively limited. Indeed, Chenery and Shrinivasen (1988) argue that exports generate greater growth as a result of greater capacity utilisation; greater horizontal specialisation as firms concentrate on narrower range of products; increasing familiarity with new technologies; greater learning by doing and the stimulative effect of the need to achieve greater internationally acceptable quality standards.
Despite the reforms, South Africa's share of the world's trade in motor vehicles remains small. The industry also remains a net user of foreign exchange. There is therefore a clear need to enhance the volume of South Africa's exports of motor vehicles. Two sets of factors play a role in stimulating exports: demand-side and supplyside factors. The MIDP to a great extent focuses on the supply-side. This paper focuses to a great extent on the demand side factors due to data limitations. The main questions to be answered are as follows;

(a) Which countries has South Africa exploited with its automobile export potential?

(b) Which countries has South Africa not reached with its export potential?

(c) Are there barriers to exploiting the export markets?

We attempt to answer these questions using a gravity model of trade. In its basic form, a gravity model expresses that the amount of trade between South Africa and its trading partners increases with their size as measured by national incomes and diminishes with the cost of transportation between them, proxied by the distance between their economic centres.

We further employ the gravity model to predict within-sample potential export trade flows for motor vehicles, parts and accessories (SIC 381383 ) given certain conditions. A gravity model has been constructed by the International Trade Centre (ITC) called TradeSim (International Trade Centre, 2003). It estimates bilateral trade flows of developing countries with any of their partner countries. With regard to South Africa, TradeSim shows that there is untapped trade potential in the United States for motor vehicles and other transport equipment.

The novelty of our paper lies in three areas. First, we employ a static two-way error component panel data model, which includes both time-specific fixed effects and crosssection specific fixed effects. Second, we solve the baseline gravity model deterministically and compute export potential for 71 countries. Finally, we attempt to identify some of the factors that tend to inhibit NAAMSA members from exploiting the identified unexploited export markets. 
The rest of the paper is organised as follows. Section 2 presents the background of the South Africa's automotive industry as well as the gravity model. Section 3 presents the model, estimation framework and the data. Section 4 focuses on the results and estimation of export potential. The last section deals with the conclusions.

\section{2 \\ Background of South Africa's automotive industry}

Table 1 outlines some key automotive industrial policy periods and key instruments. South Africa's automotive industry started with car assembly plants in 1920s, which mainly served the needs of the local market. The motor industry developed very small plants producing different models and in some cases different makes at very high unit costs (Black, 1994). Cars were mainly assembled locally from imported components with about 20 per cent local content. During this period, South Africa followed an import substitution industrial policy, which entailed imposing heavy tariffs that increased with valueadded (Barnes, Kaplinsky and Morris, 2004).

South Africa's isolation under the apartheid regime led to trade boycotts and sanctions, which had negative effects on foreign exchange earnings especially in the 1960s and the 1980s following the infamous Rubicon speech in 1985. The government responded by introducing local content requirements, which the local assemblers were supposed to observe.

The Local Content Programme (LCP) evolved over six phases from 1961-1995. During phases I to V, the LCP was based on weight, which varied from 15 per cent in 1961 to 66 per cent in 1980 (Franse, 2006). South African assemblers not meeting the local content requirements were subjected to prohibitively high import tariffs. This led to the emergence of a domestic components industry (Black \& Mitchell, 2002).

In 1989, the South African government started to move away from import substitution towards an industrial policy promoting export. Local content requirement was reduced from 66 per cent to 50 per cent. The aim of the policy was to expand the size of the market for firms and thus force them to rationalise the completely builtup (CBU) vehicles and component markets. This led to an increase in exports of component markets with limited change in CBUs.

Table 1

Development of automotive policy in South Africa

\begin{tabular}{|c|c|c|}
\hline Period & Automotive policy & Key instruments \\
\hline $\begin{array}{l}\text { June } 1961- \\
\text { February } 1989\end{array}$ & $\begin{array}{l}\text { Phases I-V } \\
\text { Local content } \\
\text { programme }\end{array}$ & $\begin{array}{l}\text { - Varying local content level based on weight } \\
\text { - Excise duty rebate scheme }\end{array}$ \\
\hline $\begin{array}{l}\text { March 1989- } \\
\text { August } 1995\end{array}$ & $\begin{array}{l}\text { Phase VI } \\
\text { Structural adjustment } \\
\text { programme }\end{array}$ & $\begin{array}{l}\text { - Local content scheme adjusted for value targets } \\
\text { - Import-export complementation (IEC) scheme } \\
\text { introduced }\end{array}$ \\
\hline $\begin{array}{l}\text { September 1995- } \\
\text { June } 2000\end{array}$ & Phase I of MIDP & $\begin{array}{l}\text { - Local content regulations abolished } \\
\text { - Tariff phase-down for imported models and } \\
\text { components (imported vehicles } 40 \% \text { and } \\
\text { components } 30 \% \text { by 2002) } \\
\text { - Export credits increased } \\
\text { - Duty free allowance (DFA) and small vehicle } \\
\text { incentive (SVI) scheme implemented }\end{array}$ \\
\hline
\end{tabular}




\begin{tabular}{|c|c|c|}
\hline July 2000-2007 & Phase II of MIDP & $\begin{array}{l}\text { - Tariff phase-down to continue until } 2007 \text { (imported } \\
\text { vehicles 30\% and components 25\%) } \\
\text { - IEC phase-down from 2003-2007 } \\
\text { - Introduction of new production-based duty free } \\
\text { allowance in } 2000 \\
\text { - Introduction of production asset allowance (PAA) } \\
\text { but to be discontinued by } 2007\end{array}$ \\
\hline 2007-2012 & Phase III of MIDP & $\begin{array}{l}\text { - Tariff phase-down to continue until } 2012 \text { (imported } \\
\text { vehicles } 25 \% \text { and components } 20 \% \text { ) }\end{array}$ \\
\hline
\end{tabular}

Source: The Department of Trade and Industry (DTI), 2004

In 1995 the government introduced the MIDP with a view to helping the motor industry adjust to South Africa's reintegration into the global economy (Flatters, 2005). The objectives of MIDP were to improve the international competitiveness of South Africa's automotive and associated industries; improve vehicle affordability in the domestic market; encourage growth in the vehicle market and in the component manufacturing industry particularly in the field of exports; stabilise employment levels in the automotive industry; and create a better balance between the industry's foreign exchange usage and foreign exchange earnings. There were four key features of the MIDP; (a) Reduce tariffs on light vehicles and components, with tariffs being phased down faster than required by the WTO obligations;

(b) Removal of local content requirements;

(c) Duty free import of components up to 27 per cent of the wholesale value of the vehicle; and

(d) Duty-rebate credits to be earned on exports of vehicles and components and to be used for duty-free imports of vehicles and components. Thus, the MIDP grants a production-asset allowance to vehicle manufacturers that invest in new plants and equipment, giving them 20 per cent of their capital expenditure back in form of import duty credits over a period of 5 years.

\section{Table 2}

Selected indicators of South Africa's automotive industry

\begin{tabular}{|c|c|c|c|c|c|c|c|c|c|c|c|}
\hline & 1995 & 1996 & 1997 & 1998 & 1999 & 2000 & 2001 & 2002 & 2003 & 2004 & 2005 \\
\hline \multicolumn{12}{|l|}{$\begin{array}{l}\text { Market for Cars, Light Commercial Vehicles, } \\
\text { Medium and Heavy Trucks and Buses }\end{array}$} \\
\hline $\begin{array}{l}\text { Domestic Sales of Domestically Produced } \\
\text { Vehicles }\end{array}$ & 373712 & 374758 & 342535 & 286159 & 266349 & 289333 & 297856 & 279135 & 294674 & 344545 & 387700 \\
\hline Exports & 15764 & 11553 & 19569 & 25896 & 59716 & 68031 & 108293 & 125308 & 126661 & 110507 & 143400 \\
\hline Total Dome stic Production & 389476 & 386311 & 362104 & 312055 & 326065 & 357364 & 406149 & 404443 & 421335 & 455052 & 531100 \\
\hline Exports as \% of Domestic Production & 4 & 3 & 5 & 8 & 18 & 19 & 27 & 31 & 30 & 24 & 27 \\
\hline Imports & 26255 & 46318 & 56740 & 65351 & 59426 & 65299 & 84673 & 84049 & 87926 & 136975 & 219200 \\
\hline Total Local Market (Including Imports) & 399967 & 421076 & 399275 & 351510 & 325775 & 354632 & 382529 & 363184 & 382600 & 481520 & 606900 \\
\hline Imports as \% of Local Market & 7 & 11 & 14 & 19 & 18 & 18 & 22 & 23 & 23 & 28 & 36 \\
\hline Component Exports (Million Rands) & & & & & & 12640 & 18595 & 23183 & 21270 & 21736 & \\
\hline \multicolumn{12}{|l|}{ Indus try Employment Levels } \\
\hline Vehicle Manufacturing Ind ustry & & & & & 32000 & 32300 & 32700 & 32370 & 31700 & 31800 & 33825 \\
\hline Automotive Components & & & & & 67200 & 69500 & 72100 & 74100 & 75000 & 74500 & 78000 \\
\hline Tyre Industry & & & & & 6670 & 6575 & 6300 & 6000 & 6000 & 6000 & 6000 \\
\hline Motor Trade, Distribution and Servicing & & & & & 175000 & 180000 & 182000 & 185000 & 191000 & 194000 & 195000 \\
\hline Total Employment & & & & & 280870 & 288375 & 293100 & 297470 & 303700 & 306300 & 312825 \\
\hline
\end{tabular}


The MIDP has given the OEMs the opportunity to scale down on the number of models produced locally and to import models, which were less economically viable to produce. The MIDP has allowed auto makers to concentrate on manufacturing certain vehicles or components for export while importing other models. Since its inception, the MIDP has been subjected to two reviews: 1999 and in 2002. Phase I of MIDP was operational from September 1995 to June 2000. The first review extended the programme from July 2000 to 2007 while the second review extended it to 2012.

Table 3

South Africa's exports to some selected Countries

\begin{tabular}{|c|c|c|c|c|c|}
\hline \multirow[b]{2}{*}{ Country } & \multirow[b]{2}{*}{ Total (1988-2004) } & \multicolumn{3}{|c|}{ Ranking } & \multirow[b]{2}{*}{$\begin{array}{l}\text { Deviation(pre us } \\
\text { post 1994) }\end{array}$} \\
\hline & & (1988-1993) & Total (1994-2004) & $1988-2004$ & \\
\hline Germany & 4229626840 & 1 & 1 & 1 & 0 \\
\hline United States & 3007962528 & 2 & 2 & 2 & 0 \\
\hline United Kingdom & 2701416405 & 6 & 3 & 3 & 3 \\
\hline Japan & 2557029910 & 10 & 4 & 4 & 6 \\
\hline Australia & 1739649515 & 13 & 5 & 5 & 8 \\
\hline Zimbabwe & 1150697337 & 3 & 6 & 6 & -3 \\
\hline Belgium & 747775669 & 7 & 7 & 7 & 0 \\
\hline China & 670380911 & 4 & 9 & 8 & -5 \\
\hline Mozambique & 639703073 & 8 & 8 & 9 & 0 \\
\hline Zambia & 572340017 & 5 & 11 & 10 & 6 \\
\hline Netherlands & 493645754 & 11 & 10 & 11 & 1 \\
\hline Malawi & 441910508 & 9 & 12 & 12 & -3 \\
\hline Spain & 270694274 & 15 & 14 & 13 & 1 \\
\hline Singapore & 269636136 & 24 & 13 & 14 & 11 \\
\hline Italy & 181809392 & 14 & 16 & 15 & -2 \\
\hline $\begin{array}{l}\text { Hong Kong Special Administrative } \\
\text { Region of China }\end{array}$ & 175160143 & 16 & 15 & 16 & 1 \\
\hline Kenya & 161039673 & 21 & 17 & 17 & 4 \\
\hline France & 148270573 & 17 & 18 & 18 & -1 \\
\hline New Zealand & 122846986 & 34 & 19 & 19 & 15 \\
\hline Brazil & 113155325 & 18 & 20 & 20 & -2 \\
\hline Mauritius & 94483467 & 20 & 22 & 21 & -2 \\
\hline United Republic of Tanzania & 91829263 & 29 & 21 & 22 & 8 \\
\hline Angola & 87975245 & 23 & 23 & 23 & 0 \\
\hline India & 77302554 & 36 & 24 & 24 & 12 \\
\hline Republic of Korea & 71223532 & 38 & 25 & 25 & 13 \\
\hline Democratic Republic of the Congo & 61991500 & 12 & 34 & 26 & -22 \\
\hline Ghana & 57901643 & 59 & 26 & 27 & 33 \\
\hline Malaysia & 52401659 & 44 & 27 & 28 & 17 \\
\hline Thailand & 47855829 & 54 & 28 & 29 & 26 \\
\hline Sweden & 40902554 & 58 & 29 & 30 & 29 \\
\hline Canada & 40620110 & 32 & 30 & 31 & 2 \\
\hline Nigeria & 36734211 & 65 & 31 & 32 & 34 \\
\hline United Arab Emirates & 36652862 & 46 & 32 & 33 & 14 \\
\hline Uganda & 33026629 & 52 & 33 & 34 & 19 \\
\hline Portugal & 30904752 & 19 & 19 & 35 & 0 \\
\hline Mexico & 29258765 & 30 & 35 & 36 & 5 \\
\hline Cameroon & 26782704 & 22 & 41 & 37 & -19 \\
\hline Madagascar & 25870407 & 50 & 36 & 38 & 14 \\
\hline Israel & 25241477 & 26 & 40 & 39 & -14 \\
\hline Russian Federation & 24785874 & 104 & 37 & 40 & 67 \\
\hline Greece & 24228945 & 27 & 39 & 41 & -12 \\
\hline Argentina & 18913406 & 31 & 42 & 42 & -11 \\
\hline Switzerland & 15929559 & 33 & 46 & 43 & -13 \\
\hline Gabon & 14213641 & 67 & 43 & 44 & 24 \\
\hline Indonesia & 13952519 & 86 & 44 & 45 & 42 \\
\hline Antigua and Barbuda & 13723421 & 84 & 45 & 46 & 39 \\
\hline Saudi Arabia & 13107612 & 25 & 58 & 47 & -33 \\
\hline Seychelles & 12976308 & 41 & 49 & 48 & -8 \\
\hline Turkey & 12450734 & 61 & 47 & 49 & 14 \\
\hline CH & 12062098 & 60 & 48 & 50 & 12 \\
\hline
\end{tabular}

Source: Computed using exports data collected from Quantec research (http://ts.easydata.co.za). 


\subsection{Automotive industry export performance}

South Africa's export of motor vehicles and components has increased substantially since the introduction of the MIDP in 1995 (tables 2 and 3). Table 3 presents data on South Africa's export of motor vehicle, parts and accessories over the period 1988-2004. Column 2 of Table 3 shows the total exports over the period 1988 to 2004 in US dollars. Columns 3, 4 and 5 of Table 3 present rankings of export destinations using total exports as a criterion for ranking. Three different rankings are presented; the period 1988-1993, 1994-2004 and the average over the period 1988-2004.

The ranking for the period 1988-1993 reflects South Africa's motor vehicle trade during the apartheid era. The countries that were important are Germany, United States, Zimbabwe, Zambia and United Kingdom, among others. During the post-apartheid era (1994-2004) the situation changed marginally with the emergence of Japan and the United Kingdom as major trading partners. The last column compares the ranking in the period 1988-1993 and 1994-2004. Positive figures indicate improvement in terms of ranking for that country. For instance Japan's ranking improved from 10 during the apartheid era to number 4 during the period 1994-2004.

\subsection{The gravity model}

The gravity model, first applied to international trade by Tinbergen (1962) and Pöyhönen (1963), has been used in the social sciences since the latter half of the nineteenth century to explain migration and other social flows in terms of the "gravitational forces of human interaction".

The basic form of the gravity model, true to its namesake, is analogous to the Newton's 1687 "Law of Universal Gravitation". The law holds that the gravitational force between two physical bodies ( $F_{i j}$ in Newtons) is proportional to the product of each body's mass ( $M_{i}$ and $M_{j}$ in kilograms) divided by the square of the distance between the respective centres of gravity $\left(D^{2}\right.$ in metres);

$F_{i j}=G \frac{M_{i} M_{j}}{D_{i j}^{2}}$
In 1962 Jan Tinbergen proposed that roughly the same functional form could be applied to international trade flows. Since then it has been applied to a whole range of "social interactions" including migration, tourism and investment with a lot of empirical success. The gravity law of social interaction can be expressed roughly in the same notation as equation 1 except that $M_{i}$ and $M_{j}$ are redefined as the economic sizes of the two locations.

The gravity model has gone from a theoretical orphan to being the favoured child of all main theories of international trade. Despite its use in many early studies of international trade by Tinbergen (1962), Pöyhönen (1963) and Linnemann (1966), the gravity model was considered suspect because it had no theoretical foundation.

Leamer and Stern (1970) provided the first foundation with the "potluck assumption", that argues that nations produce their goods and throw them all into a pot; then each nation draws its consumption out of the pot in proportion to its income. They conclude that the expected value of nation $i$ 's consumption produced by nation $j$ will equal nation $i$ 's share of world GDP times nation $j$ 's share of world GDP.

Anderson (1979) was the first to provide a clear microfoundation but rested on an assumption that was viewed as ad hoc at that time, namely that each nation produced a unique good that was only imperfectly substitutable with another nation's goods.

Although, the gravity model fell into disrepute in the 1970s and early 1980s, an attempt was initiated by Bergrstrand (1985) to give it a sound microeconomic foundation. $\mathrm{He}$ developed a theoretical connection between the factor endowments theory and bilateral trade. However, he did not manage to reduce the complicated price terms to an empirically implementable equation.

A simple gravity model for South Africa's exports of motor products is

$X_{i j}=\beta_{0} Y_{i}^{\beta_{1}} Y_{j}^{\beta_{2}} \prod_{m=1}^{k}\left(z_{i j}^{m}\right)^{\beta_{m}} e^{\left(\sum_{w=1}^{\kappa} \lambda_{n} L_{i j}^{(k)}+\varepsilon_{i j}\right.}$

Where

$X_{i j}$ the value of bilateral exports of automobile products from South Africa to nation $j$. 
In line with practice, $i$ refers to origin country (South Africa) and $j$ to destination nation

$Y_{i}, Y_{j}$ South Africa and importer incomes

$\prod_{=1}^{k}\left(z_{i j}^{m}\right)^{\beta_{m}}$ A set of measures impacting either

${ }_{m=1}$ negatively or positively on trade flows from

South Africa to country $j$ but are positive so that logarithmic transformation can be applied

$\sum^{r}\left(\lambda_{i j}^{w} L_{i j}^{w}\right)$ A set of measures impacting either ${ }^{\prime}$ negatively or positively on trade flows from South Africa to country $j$ but logarithmic transformation cannot be applied e.g. dummy variabales.

$\varepsilon_{i j}$ the random error term

In this model four assumptions are made. Firstly, all goods are differentiated by place of origin (Armington Assumption). In other words automobile products from South Africa are distinguishable from others. Secondly, each country is specialised in the production of only one good. Thirdly, the supply of each good is fixed. Finally, preferences of consumers are homothetic (approximated through a constant elasticity of substitution utility function).

Equation 3 is generated by performing logarithmic transformation on Equation 2.

$$
\begin{gathered}
\ln X_{i j}=\beta_{0}+\beta_{1} \ln Y_{i}+\beta_{2} \ln Y_{j}+ \\
\sum_{m=1}^{k} \beta_{m} \ln z_{i j}^{m}+\sum_{w=1}^{r} \lambda_{w} L_{i j}^{w}+\varepsilon_{i j}
\end{gathered}
$$

\subsubsection{Remoteness variable approach}

Bilateral trade between South Africa and country $j$ depends on the bilateral trade barrier, $t_{i j}$, relative to all other partners. As pointed out by Anderson (1979), bilateral trade flows are a function of the bilateral trade barrier relative to the average barrier of the two countries with all their partners after controlling for country size. Consequently a remoteness variable is included in Equation 2 to proxy for this average trade barrier. Remoteness of country $i$ is usually computed as in Anderson and van Wincoop (2003: 173);

$\mathrm{R} E M_{i}=\sum_{m \neq j}^{m}\left(\frac{d_{i m}}{y_{m}}\right)$

Where $d_{i m}$ is the distance of country $i$. This variable is intended to reflect the average distance of country $i$ from all trading partners other than $j$.

However, as argued by Anderson and van Wincoop (2003), this approach, which relies solely on distance, does not capture the entire range of factors impeding bilateral trade flows. Therefore the gravity model in Equation 3 suffers from omitted variable bias.

\subsubsection{Multilateral (price) resistance terms approach using price indices}

Anderson and van Wincoop (2003) suggest a theoretical gravity specification based on the approaches of Anderson (1979), Bergstrand (1989) and Deardorff (1998), which explicitly takes into account "multilateral (price) resistance" terms. These multilateral resistance terms consist of country specific price indices, $p_{i}$ and $p_{j}$. Consequently, bilateral trade between country $i$ and country $j$ is dependent on the following;

$\left(\frac{t_{i j}}{p_{i} p_{j}}\right)^{1-\sigma}$

Where $\sigma$ is the elasticity of substitution between all goods.

Unfortunately, the multilateral trade barriers suggested in equation 5 are unobservable. However, it is possible to use a fixed effects model as suggested by Anderson and Van Wincoop (2003).

Equation 6 is an "augmented gravity model" of trade, which has been modified to include the multilateral terms.

$$
\begin{aligned}
& \ln X_{i j}=\beta_{0}+\beta_{1} \ln Y_{i}+\beta_{2} \ln Y_{j}+(1-\sigma) \rho \ln d_{i j}+\sum_{m=3}^{k} \beta_{m} \ln z_{i j}^{m}+\sum_{w=1}^{r} \lambda_{w} L_{i j}^{w}+(1-\sigma) \ln p_{i}+ \\
& (1-\sigma) \ln p_{j}+\varepsilon_{i j}
\end{aligned}
$$




\section{3}

\section{The Model}

\subsection{Model specification}

The gravity model has traditionally been estimated using cross-section data. However, this has been shown to generate biased results since typically heterogeneity among the countries is not appropriately controlled for.
With heterogeneity, South Africa may export different amounts to two different countries, even though the two export markets have the same GDPs and are equidistant from the South Africa.

The panel data approach attempts to solve the problem by permitting more general types of heterogeneity. Our study follows the panel data analysis approach. The basic static gravity model is specified as follows;

$$
\begin{aligned}
& \ln X_{i j t}=\beta_{0}+\phi \ln X_{i j t-1}+\beta_{1} \ln \left(Y_{i t}\right)+\beta_{2} \ln \left(Y_{j t}\right)+\beta_{3} \ln d_{i j}+\beta_{4} \ln p_{i t}+\beta_{5} \ln p_{j t}+\beta_{6} \ln \text { tar }_{j t}+ \\
& \lambda_{1} g e_{j t}+\lambda_{2} r q_{j t}+\lambda_{3} c c_{j t}+\lambda_{4} \text { lang }_{j}+\lambda_{5} A F R_{j}+\lambda_{6} S A D C_{j}+\lambda_{7} E U_{j}+\lambda_{8} N A F T A_{j}+\lambda_{9} A S I A_{j}+ \\
& \lambda_{10} M E_{j}+\lambda_{11} M E R C+\lambda_{12} \text { Drive }_{j}+\varepsilon_{i j t}
\end{aligned}
$$

Where:

$X_{i j t}$ : Foreign price value (e.g. US dollars) of exports of goods by South Africa to country $i$;

$Y_{i}$ : South Africa's GDP in US dollars;

$d_{i j}$ : The geographical distance between South Africa's economic centre of gravity (capital cityPretoria) and the trading partner's economic centre of gravity (capital city);

$p_{i}$ : South Africa's price index using the GDP deflator;

$p_{j}$ : Importer's price index using the GDP deflator;

tar: Most favoured nation (MFN) import tariffs applied on motor equipment by the trading partner. This is a normal non-discriminatory tariff charged on imports (excludes preferential tariffs under free trade agreements and other schemes or tariffs charged inside quotas);

$g e_{j}:$ Index of government effectiveness in the trading partner;

$r q_{j}$ : Index of regulatory quality in the trading partner;

$c c_{j}$ : Index for control of corruption by the trading partner;

Lang: $_{j}$ English language dummy. Trading partners, whose official language is English, are coded 1 and otherwise 0 ;

$A F R_{i}$ : African countries dummy (African countries coded 1 and otherwise 0);

$S A D C_{j}$ : SADC member state dummy (SADC countries coded 1 and otherwise 0 );

$E U_{j}$ : European Union dummy (EU members coded 1 and otherwise 0);

NAFTA $A_{j}$ : North American Free Trade Agreement dummy (NAFTA members coded 1 and otherwise 0);

$A S I A_{j}$ : Asian countries dummy (Asian countries coded 1 and otherwise 0);

$M E_{j}$ : Middle East dummy (Middle East countries coded 1 and otherwise 0);

$M E R C_{i}$ : MERCOSUR FTA dummy (MERCOSUR members coded 1 and otherwise 0);

Drive: Keep left driving dummy (Countries where vehicles keep left are coded 1 and otherwise 0 ). In South Africa drivers are expected to keep left, which implies that production plants are designed to manufacture right hand-driven vehicles and components to be fitted on the same; and

$\varepsilon_{i j t}$ : captures all the factors that influence exports but not included in equation 6 . 
$i=$ Trading partners (See column 1 of tables $6 \mathrm{a}$ and $6 \mathrm{~b}$ )

$t=1994,1995, \ldots, 2004$

Expectation: $\quad \phi><0, \beta_{1}>0, \beta_{2}>0, \beta_{3}<0, \beta_{4}<0, \beta_{5}<0, \beta_{6}<0, \lambda_{1}>0, \lambda_{2}>0, \lambda_{3}>0, \lambda_{4}>0, \lambda_{5}>0$,

$$
\lambda_{6}>0, \lambda_{7}><0, \lambda_{8}><0, \lambda_{9}><0, \lambda_{10}><0, \lambda_{11}><0, \lambda_{12}>0 \text {, }
$$

The error term, $\varepsilon_{i j t}$, is decomposed as a two-way error component model i.e. $\varepsilon_{i j t}=\mu_{i}+\lambda_{t}+v_{i j t}$. Where $\mu_{i}$ is the country-specific effects, $\lambda_{t}$ is time specific effects and $v_{i j t}$ is the remainder white noise stochastic error term, which varies with countries and time.

The country-specific fixed effects $\left(\mu_{i}\right)$ are time-invariant characteristics of the different countries. These include;

(i) The unobservable socio-political environment in each of the countries

(ii) Trading partner's love for "South African attributes" embedded in motor vehicles and component exports. For instance, South Africa has several unique technologies, such as differential locks for off-road vehicles, aluminium welding technology for radiators, and the ability to design components such as air cleaners and air conditioners that are able to cope with the higher temperatures and dust levels in Africa

(iii) The unobservable contribution of the state of international relations between South Africa and the trading partner. It could also capture the unobservable contribution of the trade officers and other officials in South Africa's diplomatic missions abroad (Consulates, embassies and high commissions).
The use of unobservable country specific fixed effects is predicated on the need to incorporate their effects in the model despite the difficulty to explicitly model them. The difficulties emanate from lack of knowledge regarding the actual factors or lack of data.

The time-specific fixed effects $\left(\lambda_{t}\right)$ are cross-section invariant and capture the various policy interventions, motor vehicle trade liberalisation policies, changes in product quality owing to innovations in South Africa. It may include;

(i) Product innovations that change the attributes of South African motor vehicles and components;

(ii) The country-invariant effect of the introduction of the MIDP in 1995;

(iii) The different phases of MIDP;

(iv) The effect of the government of national unity in South Africa since 1994;

(v) The Asian crisis of 1997;

(vi) Argentina/Mexican/Russian crisis of 199899; and

(vii) The rand collapse in 2001

Equation 7 can now be re-specified as follows;

$$
\begin{aligned}
& \ln X_{i j t}=\beta_{0}+\mu_{j}+\lambda_{t}+\beta_{1} \ln \left(Y_{i t}\right)+\beta_{2} \ln \left(Y_{j t}\right)+\beta_{3} \ln d_{i j}+\beta_{4} \ln p_{i t}+\beta_{5} \ln p_{j t}+\beta_{6} \ln \text { tar }_{j t}+ \\
& \lambda_{1} g e_{j t}+\lambda_{2} r q_{j t}+\lambda_{3} c c_{j t}+\lambda_{4} \text { lang }_{j}+\lambda_{5} A F R_{j}+\lambda_{6} S A D C_{j}+\lambda_{7} E U_{j}+\lambda_{8} N_{A F T A_{j}}+\lambda_{9} A S I A_{j}+ \\
& \lambda_{10} M E_{j}+\lambda_{11} M E R C+\lambda_{12} \text { Drive }_{j}+v_{i j t}
\end{aligned}
$$

\subsection{Estimation framework}

In using the panel data approach, a number of challenges must be addressed. These include zero trade, estimating country fixed effects and time-invariant regressors, and endogeneity.

\subsubsection{Dealing with zero trade flows}

The log-linearised model in equation 8 is not defined for observations with zero trade. There are various approaches to handle the presence of zeros. These include discarding the zeros from the sample, adding a constant factor to each observation on the dependent variable, 
estimating the gravity in nonlinear form using the fixed effects Poisson maximum likelihood estimator and the use of unbalanced panel estimation techniques.

\subsubsection{Heteroscedasticity and serial correlation}

The log-linearised model in equation 8 may be both biased and inefficient in the presence of heteroscedasticity. This is corrected by using cross-section and period weights in the estimation. To avoid serial correlation, one of the models in Table 5 is estimated in dynamic form.

\subsubsection{Estimating effects and time-invariant regressors simultaneously}

The effects of time-invariant regressors like distance, language, etc. can be estimated using a random effects model (REM). REM assumes that the effects are randomly distributed across the different countries. However, the random effects coefficients cannot be interpreted since they cannot be attributed to a specific trading partner.

The alternative is to estimate country-specific fixed effects model (FEM), using WITHIN estimation (demeaning before OLS) in which the coefficients are interpreted as the unobserved effects of each country. The problem with estimating country-specific fixed effects and time-invariant regressors simultaneously is perfect multicollinearity. The problem emanates from the fact that both country-specific fixed effects and the time-invariant factors are captured by using dummy variables.

The study follows the approach of Cheng and Wall (2005). This approach uses two steps. The first step entails estimating a modified form of Equation 8 excluding the time-invariant variables. The country-specific fixed effects $\left(\hat{\mu}_{j}\right)$ are regressed on other time-invariant variables as follows;

$$
\begin{aligned}
& \hat{\mu}_{j}=\theta_{0}+\theta_{1} \ln d_{i j}+\theta_{2} \text { lang }_{j}+\theta_{3} A F R_{j}+\theta_{4} S A D C_{j}+\theta_{5} E U_{j}+\theta_{6} N A F T A_{j}+\theta_{f} A S I A_{j}+ \\
& \theta_{8} M E_{j}+\theta_{9} M E R C_{j}+\theta_{10} \text { Drive }_{j}+\eta_{i j t}
\end{aligned}
$$

\subsection{Data descriptions}

Sample of countries: 71 countries are selected on the basis of importance to South Africa's automotive exports as well as availability of data for variables described in equations 8 and 9 .

Exports: Standard industrial classification (SIC) level 2 exports data in nominal US dollars, are collected from Quantec Research (http:// ts.easydata.co.za). Date accessed $21^{\text {st }}$ August 2005. The exports data cover motor vehicles, parts and accessories (SIC 381-383).

Distance: Distance captures both export transaction costs and costs of searching and finding information regarding export markets (economic reports, country risk reports, foreign market demand reports, etc.). Data in kilometres are collected from http://www.indo. com/distance/.

GDP, Population: Collected from International Monetary Fund's International Financial Statistics.
Language: An English language dummy variable ( 0 or 1$)$ is created, which takes into account common national language (official or not). The assumption here is that the official language in South Africa is English. It is imperative to note that there are 9 official languages in South Africa. However, the main commercial languages are English and Afrikaans.

Import tariffs: Most favoured nation (MFN) import tariffs applied (percentage) on transport equipment by the trading partner. These are normal non-discriminatory tariffs charged on imports (excluding preferential tariffs under free trade agreements and other schemes or tariffs charged inside quotas). http://stat.wto. org/TariffProfile. Accessed in August 2007. One limitation is that the tariffs are for a much broader category (transport equipment).

Government effectiveness: This index describes the ability of governments to effectively deliver public services and make policy. The index ranges from -2.5 (worst governance) and 2.5 (best governance). The data is collected from 
http://www.govindicators.org. Date accessed $30^{\text {th }}$ December 2005.

Regulatory quality: This is a measure of the ability of the government to formulate and implement sound policies and regulations and promote private sector development. The index ranges from -2.5 (worst governance) and 2.5 (best governance). The data is collected from http://www.govindicators.org . Date accessed $30^{\text {th }}$ December 2005.

Control of corruption: This measures the extent to which public power is exercised for private gain, including petty and grand forms of corruption, as well as "capture" of the state by elites and private interests. The data is collected from http://www.govindicators.org. Date accessed 30 ${ }^{\text {th }}$ December 2005.

European Union (EU) dummy: Europe is South Africa's biggest source of investment, accounting for almost half of South Africa's total foreign trade. In 1999 South Africa concluded a trade agreement with the EU called the Trade, Development and Co-operation Agreement (TDCA). The Afrikaans community has a cultural link with the EU since they originated from Netherlands. EU dummy is created by coding EU members with 1 and otherwise 0.

North American Free Trade Agreement (NAFTA) dummy: NAFTA is the trade bloc in North America created on January 1, 1994. South Africa is beneficiary of the US's Generalised System of Preferences (GSP) which grants duty-free status to some 4650 goods. NAFTA members are coded 1 and otherwise 0 .

African dummy: A number of local communities in South Africa originated in Southern, Eastern and Central Africa. South Africa is a member of the African Union (AU) and hosts Pan African Parliament and the New Partnership for Africa's Development (NEPAD) secretariat. South Africa has access to the African continent since it is perceived as the "big brother" by a number of countries. The African dummy is created by coding African countries with 1 and otherwise 0 .

Asian dummy (excluding Middle East): Asia is the world's largest and most populous continent.
Since 1994, South Africa has continued to strengthen its relations with Asia through increases in two-way trade and finalising cooperation agreements involving scientific and technological exchange, technology transfer, investments and overseas development assistance. Asian countries are coded 1 and otherwise 0 .

Middle East dummy: The Middle East is becoming an important trade zone for South Africa. It holds great potential for South Africa as an export market, and serves as a potential strategic source of foreign direct investment. Middle East countries are coded 1 and 0 otherwise.

South America (MERCOSUR): The Mercosur is a trading bloc created by Argentina, Brazil, Paraguay and Uruguay in 1991, and later joined by Mexico and Venezuela. Bolivia, Chile and Peru are associate members. In December 2000, a framework agreement for the creation of a free trade agreement was signed by South Africa and MERCOSUR. MERCOSUR FTA dummy is created by coding MERCOSUR members as 1 and otherwise 0 .

Drive on left side dummy: About a quarter of the world, including South Africa, drives on the left. There are also countries in the sample whose inhabitants drive on the right-hand side of the road. A list of countries that keep left and right on the road is collected from http:// users.pandora.be/worldstandards/driving $\% 20$ on $\% 20$ the $\% 20$ left.htm. The drive on left side dummy variable is created by coding those countries using right hand-drive vehicles as 1 and otherwise 0 .

Importer price index: The study uses GDP deflators as a proxy for import price index. The import price index, $p_{j}$, captures a number of multilateral resistance variables $p_{j}=$ $\left[\sum_{i}\left(\frac{t_{i j}}{\Pi_{i}}\right)^{1-\sigma} \phi_{i}\right]^{\frac{1}{1-\sigma}} \cdot t_{i j}$ are all the factors that restrict trade, $\sigma$ is the elasticity of substitution between automotive products, $\phi_{i}$ is the share of South Africa's GDP in world GDP, $\Pi_{i}=p_{i}=$ $\left[\sum_{j}\left(\frac{t_{i j}}{p_{j}}\right)^{1-\sigma} \phi_{j}\right]^{\frac{1}{1-\sigma}}$ and $\phi_{j}$ is the share of importer GDP in world GDP. The data is collected from the International Financial Statistics of the IMF. 


\section{4}

\section{Estimation results}

\subsection{Regression results and discussions}

Table 5 presents the estimation results from equations 8 and 9. The first, is the pooled model in which homogeneity in terms of cross-section and time is assumed. With adjusted R-squared above 0.6 , the gravity equation explains more than half of the bilateral export trade of motor vehicles, parts and accessories. The low DurbinWatson statistic shows that the models suffer from a problem of serial correlation. .

The following emerges from the results. First, the importer GDP has the expected positive and significant effect in all the models. The magnitude of the coefficient is close to unity in all models, which is consistent with the findings in McCallum (1995) and Anderson and Wincoop (2003). The high income elasticity indicates that South Africa's automobile exports could rise significantly if her trading partners maintain strong economic growth.

Second, distance has the expected negative and significant effect on South Africa's exports of motor vehicles, parts and accessories. It means that South Africa exports less to countries that are far off. Grossman (1998) reckons that if shipping costs are at the order of 5 per cent of the value of traded goods, the trade-distance elasticity should be around -0.03 , which is much lower than the trade-distance elasticity in our study. Since distance is a proxy for transport costs, any policy that reduces costs for exporting will enhance exports of motor vehicles, parts and accessories.

Second, importer price index has the expected negative and significant effect on trade. This is not surprising since the importer price index captures a number of trade restricting factors.

Third, motor equipment MFN tariff has the expected negative sign but statistically insignificant in the pooled model. An attempt to include it in other models created perfect multicollinearity.

Fourth, importer government effectiveness, regulatory quality and control of corruption have the expected positive and significant effect. This indicates that governance issues in the importer country have a significant effect on South Africa's exports of automobile products.

Fifth, South Africa tends to export more motor vehicles, parts and accessories to Englishspeaking countries. Having the English language in common between South Africa and trading partner nations helps to build networks of trust. Institutions are also shared by increasing the degree of common cultural, literary and educational material, and by increasing the probability of migration. This affects the language policy in South Africa.

Sixth, being a member of the EU enhances South Africa's exports of automobile products to that country. This may be attributed to the positive effect of the EU-South Africa Trade Co-operation and Development Agreement of 1999 and the cultural heritage of South Africa with Europe.

Seventh, the fact that a country is a member of NAFTA enhances its imports of automobile products from South Africa. In other words there are some unobservable factors that enhance South Africa's exports of motor vehicles and parts to the United States, Canada and Mexico.

Eighth, belonging to the African continent tends to enhance South Africa's exports of automobile products to that country. This is to be expected since South Africa is perceived by many African states as the "big brother". It has played an important role in the African Union (currently hosting the African Parliament), NEPAD, solving conflicts and being the technological leader in the continent.

Ninth, membership to SADC tends to reduce trade barriers of South Africa's exports of automotive products. This is to be expected since South Africa is a key member of SADC, which implies that her exports of automotive products face preferential tariffs/treatment in member states. Additionally, some of the members within SADC belong to the South African Customs Union (SACU) and Southern Africa Monetary Union.

Tenth, membership in MERCOSUR enhances South Africa's trade in automobile products. Although trade relations between South Africa and MERCOSUR have been small, they have picked up in the recent past. South Africa signed 
a framework agreement with MERCOSUR in 2000, comprising Argentina, Paraguay, and Brazil (with Bolivia, Chile and Colombia, Ecuador, Peru and Venezueala as associate members) with the aim of forming an FTA. The agreement was eventually signed between SACU and MERCOSUR in 2004.

Eleventh, membership in Middle East and Asia has had a positive effect on South Africa's exports of automotive products. This shows that South Africa should attempt to enhance her trading relations with countries in the Middle East and Asia.
Twelfth, South Africa's export of motor vehicles, parts and accessories designed for vehicles driving on the left are obviously preferred by trading partners that drive on the left hand side.

Thirteenth, the positive (negative) effects show that these are unobservable characteristics that tend to enhance (inhibit) South Africa's exports of motor vehicles, parts and accessories to the countries in the sample. These time-specfic fixed effects reflect that initially the industry tended to struggle with high production costs. However, after 2001 the MIDP programme contributed to the sector's export performance.

\section{Table 5}

Estimation for motor vehicles, parts and accessories (SIC 381-383)

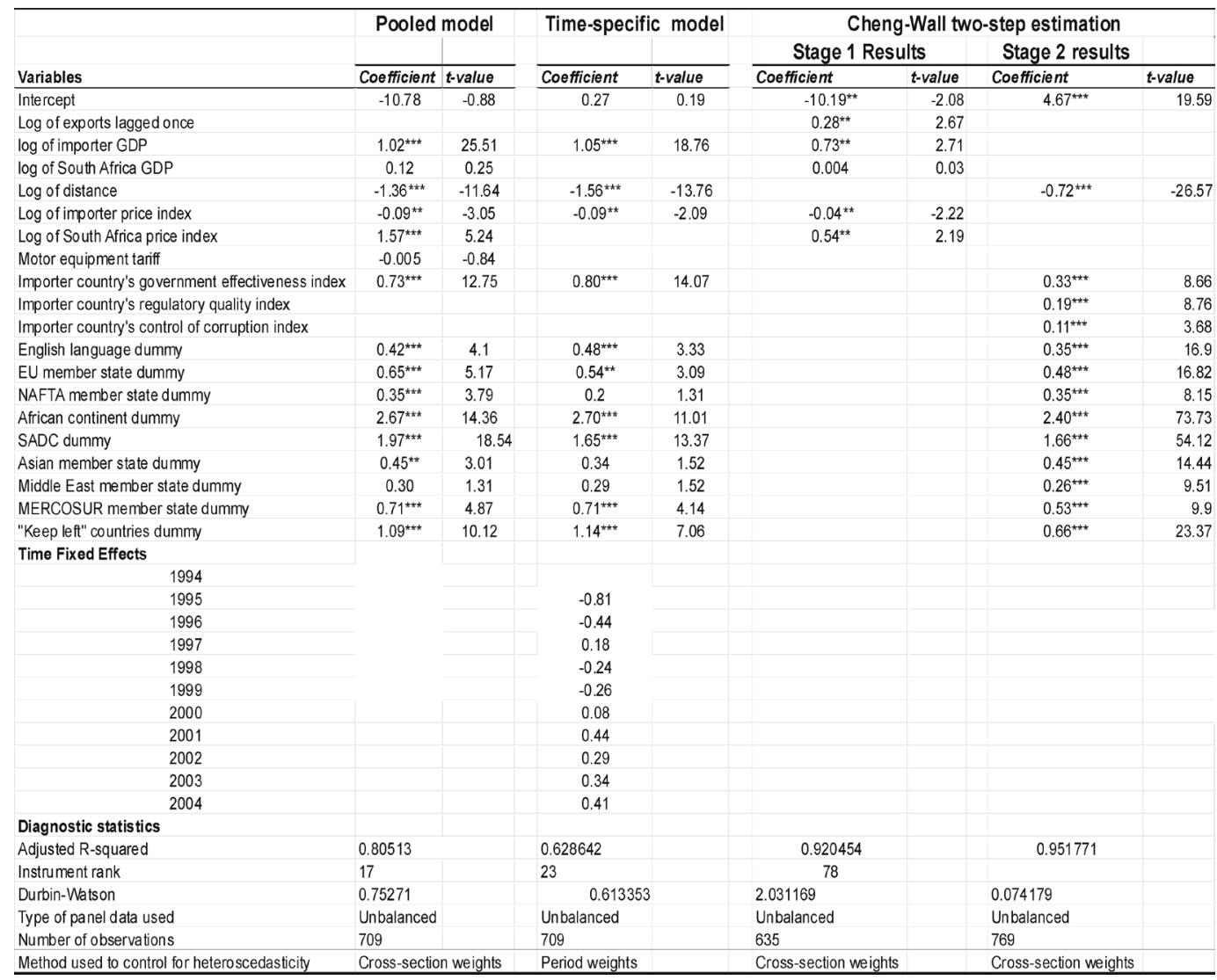

Notes: (i) Country-specific effects from stage 1 of Cheng-Wall model are presented in tables $6 \mathrm{a}$ and $6 \mathrm{~b}$

(ii) $* * *, * *$ and $*$ refer to significance at $1 \%, 5 \%$ and $10 \%$ respectively

(iii) White cross-section standard errors used to correct for heteroscedasticity 
Finally, the estimates for country-specific effects are presented in column 7 of tables $6 \mathrm{a}$ and $6 \mathrm{~b}$. On the one hand, the positive coefficients indicate that there are unobservable characteristics in those countries (column 1 of tables $6 a$ and $6 \mathrm{~b}$ ), which enhance South Africa's exports of motor vehicles, parts and accessories to those countries. Examples include Mozambique, Congo and United Kingdom. On the other hand, there are unobservable country-specific characteristics that tend to inhibit South Africa's exports of motor vehicles, parts and accessories to countries like Italy, Peru and Kuwait. From a policy perspective, it is imperative to conduct a survey on motor vehicle exporters to determine the other factors that may hamper trade to the countries that have negative country-specific effects.

\subsection{Potential exports}

There are basically two approaches to computing trade potential. The first approach obtains withinsample trade potential as the difference between estimated trade from actual trade relations between countries. The second approach derives out-of-sample trade potential estimates (e.g. Brülhart \& Kelly, 1999). In this approach, gravity model parameters are estimated and applied to forecast "natural" trade relations between countries. The difference between the observed and predicted trade flows represent the unexhausted trade potential.

Whichever approach is used, the finding of untapped trade potential calls for proactive export promotion policies e.g. bilateral and multilateral agreements, trade facilitation etc. To the contrary, finding actual trade exceeding potential trade (successful partnership) implies that trade has reached its potential level and no social cost is anticipated from future integrations.

A model is constructed from stage 1 results of the Cheng-Wall model in Table 5 and solved deterministically to determine within-sample potential exports of motor vehicles, parts and accessories. The choice of this model is predicated by the fact that it addresses many of the problems in the gravity equation. These entailed calculating the predicted values of exports, $\hat{X}_{\text {sit }}$ i.e. export potential is equivalent to the within-sample predictions.

It is imperative to note that the export potentials are dependent on the nature of the sample specification employed in this study. This means that our potential exports should be understood in the context of the specified model we have used. Different specification and sample selection may lead to different results.

Column 1 of Table 6 presents the countries in the sample. Column 2 presents the export potential in US dollars, which is computed as follows;

$$
\text { Potential }=\text { predicted }- \text { actual }
$$

Where predicted and actual represents the predicted and actual exports of motor vehicles, parts and accessories, respectively. Column 3 is the ranking of the countries on the basis of unexploited export potential. On the basis of this ranking, Mozambique has the highest untapped export potential that South Africa should explore ways of taking advantage of. The finding of untapped export in Table 6 calls for proactive export promotion policies e.g. bilateral and multilateral agreements, trade facilitation etc. To the contrary, if actual trade exceeds potential trade (successful partnership) it implies that trade has reached its potential level and no social cost is anticipated from future integrations.

Column 4 shows the ranking of the countries on the basis of actual exports. For instance despite the fact that Mozambique has the highest export potential, it is ranked number 8 in terms of importance to South Africa. Columns 7-12 present some important characteristics regarding the trading partners in question. The point is that even though export potential exists in a particular country, the characteristics presented in columns 7-12 could make it difficult for the National Association of Automobile Manufacturers of South Africa (NAAMSA) members to exploit that opportunity.

Column 7 indicates whether a trading partner is a WTO member state or not. If a country is a member of the WTO, it is obliged to observe some specific rules and principles such as most favoured nation (MFN), national treatment, 
reciprocity, transparency etc. For instance under the MFN principle, a product made in one member state should be treated no less favourably than a "like" good that originates in any other country.

Column 8 presents the average applied MFN tariffs for motor equipment. High tariffs imposed by trading partners increase the final price of the motor vehicles or components from South Africa.

Column 10 presents the rule of law. South Africa exports to countries with good rule of law. These include Japan, the US, UK etc. The point is that NAAMSA members may be limited in exploiting business opportunities due to unreliable rule of law in the trading partners. Examples include the Russian Federation, Togo, Pakistan etc.
Column 11 presents trading agreements signed bilaterally or multilaterally with South Africa. The agreements are the African Union (African countries), South African Customs Union (SACU), Southern African Development Community (SADC), SA-EU Free Trade Agreement, AGOA, SACU-MERCOSUR.

The final column presents the state of international relations between South Africa and the trading partners. NAAMSA members could utilise South African diplomatic missions abroad in breaking into these markets. There are, however, some countries where there are no diplomatic missions such as Togo, Fiji, New Zealand, Colombia, Cyprus, Sierra Leone, and Lebanon.

Table 6a

Potential exports and other selected indicators

\begin{tabular}{|c|c|c|c|c|c|c|c|c|c|c|c|}
\hline Country & $\begin{array}{l}\text { Potential exports } \\
\text { (US\$ } 000^{\prime} \text { 's) }\end{array}$ & Ranking & $\begin{array}{l}\text { Total exports } \\
\text { (1994-2004) }\end{array}$ & Ranking & $\begin{array}{l}\text { Country-specific } \\
\text { fixed effects }\end{array}$ & WTo member? & $\begin{array}{l}\text { MFN average } \\
\text { applied tariff }\end{array}$ & $\begin{array}{l}\text { Driving } \\
\text { side }\end{array}$ & Rule of Law & Agreement & Diplomatic relations with South Africa \\
\hline Mozambique & 8727.16 & 1 & 523880225 & 8 & 4.25 & Yes & 9.4 & Leff & 0.60 & SADC, African Urion & High commission-Mapub \\
\hline Belgium & 6897.44 & 2 & 608916138 & 7 & 1.23 & Yes & 4.1 & Right & 1.47 & EUSAFTA & Embassy-Brussels \\
\hline Malawi & 6880.80 & 3 & 328121770 & 12 & 4.38 & Yes & 14.4 & Left & 0.29 & SADC, African Union & High commission-Liongwe \\
\hline Zambia & 3929.67 & 4 & 415115338 & 11 & 4.18 & Yes & 10.8 & Leff & 0.54 & SADC, African Union & High commission-Lusaka \\
\hline Kenya & 3133.28 & 5 & 151432545 & 17 & 2.42 & Yes & 6.7 & Lefl & -0.98 & Atrican Union & High commission-Nairobi \\
\hline Italy & 1940.30 & 6 & 151542758 & 16 & -1.08 & Yes & 4.1 & Right & 0.74 & EUSAFTA & Embassy-Rome, Consulate-Milano \\
\hline Malaysia & 1897.98 & 7 & 51224587 & 27 & 0.18 & Yes & 11.5 & Leff & 0.52 & & High commission-Kuala Lumpur \\
\hline Netherlands & 1285.35 & 8 & 425523431 & 10 & 0.73 & Yes & 4.1 & Right & 1.78 & EUSAFTA & Embassy-Hague \\
\hline Thailand & 89961 & 9 & 47534991 & 28 & .0 .54 & Yes & 20.7 & Lefl & -0.05 & & Embassy-Bangkok \\
\hline Portugal & 733,33 & 10 & 20124815 & 37 & -0.78 & Yes & 4.1 & Right & 1.16 & EUSAFTA & Embassy-Lisbon \\
\hline Israel & 608.19 & 11 & 19550319 & 39 & -0.68 & Yes & 3.3 & Right & 0.77 & & Embassy-TelAviv \\
\hline Democratic Republic of the Congo & 39238 & 12 & 29100308 & 34 & 1.98 & Yes & 8.8 & Right & -1.74 & SADC, African Union & Embassy-Kinshasa, consular general-Lubumbas \\
\hline Tanzana & 318.75 & 13 & 88151438 & 21 & .0 .05 & Yes & 6.7 & Left & -0.49 & SADC, African Union & High commission-Dar-Es-Salaam \\
\hline Gabon & 29260 & 14 & 14130899 & 42 & 1.74 & Yes & 15.5 & Right & -0.51 & African Union & Embassy-Libreville \\
\hline Sn Lanka & 28934 & 15 & 9778989 & 46 & 0.30 & Yes & 9.9 & Leff & -0.03 & & High commission-Colombo \\
\hline Egypt & 17625 & 16 & 8141562 & 48 & -1.14 & Yes & 12.9 & Right & -0.02 & $\begin{array}{l}\text { African Union } \\
\text { Trade } \& \text { Investment Co- }\end{array}$ & Embassy-Cairo \\
\hline Canada & 120.94 & 17 & 37245760 & 30 & -1.44 & Yes & 5.8 & Right & 1.75 & operation of 1998 & High commission-Ottewa \\
\hline China & 111.91 & 18 & 476010729 & 9 & .090 & Yes & 11.6 & Right & -0.47 & & Embassy-Beijng,Consular general-Shanghai \\
\hline & & & & & & & & & & SACU-MERCOSUR PTA & \\
\hline $\begin{array}{l}\text { Argentina } \\
\text { rieland }\end{array}$ & $\begin{array}{r}35.99 \\
3477\end{array}$ & ${ }_{20}^{19}$ & $\begin{array}{l}15427720 \\
819991\end{array}$ & ${ }_{49}^{41}$ & $\begin{array}{r}-1.22 \\
0.66\end{array}$ & $\begin{array}{l}\text { Yes } \\
\text { Yes }\end{array}$ & 13.9 & $\begin{array}{l}\text { Right } \\
\text { left }\end{array}$ & $\begin{array}{l}-0.71 \\
162\end{array}$ & (2004) & $\begin{array}{l}\text { Embassy-Buenos Aires } \\
\text { Embsy.Dutin }\end{array}$ \\
\hline Congo & 24.72 & 21 & 5781401 & 53 & 1.28 & Yes & 16.8 & Right & -1.18 & African Union & Embasy-Brazaville \\
\hline Peru & 0.27 & 22 & 242071 & 71 & .3 .55 & Yes & 6 & Right & -0.63 & & Embeassy-Lima \\
\hline Fiji & -4.90 & 23 & 341549 & 70 & -2.63 & 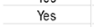 & 23.4 & Leff & -0.19 & & \\
\hline Lebanon & -11.53 & 24 & 1492467 & 67 & -1.45 & No & 4 & Right & -0.32 & & \\
\hline Finland & -13.76 & 25 & 1629863 & $\infty$ & -2.52 & Yes & 4.1 & Right & 1.97 & EUSAFTA & Embassy-Helsinli \\
\hline Sierra Leone & -15.75 & 26 & 2999227 & 58 & 1.17 & Yes & 8.1 & Right & -1.53 & African Union & \\
\hline Cypus & -18.99 & 27 & 2850590 & 59 & .0 .38 & Yes & 4.1 & Leff & 0.85 & EUSAFTA & \\
\hline Colombia & -19.60 & 28 & 8155260 & 47 & -1.65 & Yes & 13.7 & Right & -0.70 & & Embassy in Caracas (Venezuela) responside \\
\hline Pakistan & 46. & 29 & & 62 & -3.00 & Yes & 28 & Left & -0.78 & & High commission-ssamabad \\
\hline Philippines & .76 & 30 & & 61 & -186 & Yes & 8.6 & Right & -0.62 & & Embassy-Manla \\
\hline Togo & -98.02 & 31 & 627697 & $\infty$ & -1.48 & Yes & 8.7 & Right & -1.01 & African Union & \\
\hline Republic of Korea & -123.16 & 32 & 69155791 & 25 & .0 .65 & Yes & 5.4 & Right & 0.67 & & Embassy-Seoul \\
\hline Mai & -140.57 & 33 & 7110105 & 52 & 1.31 & Yes & 8.7 & Right & -0.34 & African Union & Embessy-Bamako \\
\hline Rwanda & -161.54 & 34 & 2830687 & $\infty$ & 0.92 & Yes & 22 & Right & 0.90 & African Union & Embassy-Kgali \\
\hline Kuwait & -196.18 & 35 & 2029446 & $\varpi$ & -2.18 & Yes & 4 & Right & 0.65 & & Embassy-Kuwait \\
\hline
\end{tabular}




\section{Table 6b}

Potential exports and other selected indicators

\begin{tabular}{|c|c|c|c|c|c|c|c|c|c|c|c|}
\hline Country & $\begin{array}{l}\text { Potential exports } \\
\text { (USs } 0000^{\prime} \text { s) }\end{array}$ & Ranking & $\begin{array}{l}\text { Total exports } \\
\text { (1994-2004) }\end{array}$ & Ranking & $\begin{array}{l}\text { Country-specific } \\
\text { fixed effects }\end{array}$ & WTo member? & $\begin{array}{l}\text { MFN average } \\
\text { applied tariff }\end{array}$ & $\begin{array}{l}\text { Driving } \\
\text { side }\end{array}$ & Rule of Law & Agreement & Diplomatic relations with South Africa \\
\hline 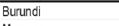 & -197.77 & 36 & 1779317 & 65 & 0.94 & Yes & 11.6 & Right & -150 & $\begin{array}{l}\text { Afican Union } \\
\end{array}$ & Embassy-Bujumbura \\
\hline Morococo & -198.04 & 37 & 3952311 & 55 & -1.22 & Yes & 18.7 & Right & .0 .05 & & RepOffice-Rabat \\
\hline Ethiopia & -221.87 & 38 & 1865195 & 64 & .0 .80 & No & 11.3 & Right & -1.00 & Afican Union & Embassy-Addis Ababa \\
\hline Switzerland & -246.11 & 39 & 13314714 & 44 & -2.48 & Yes & 4.1 & Right & 1.98 & EU-SAFTA & Embassy-Bem,Consulate-Geneva \\
\hline Czech Republic & -275.27 & 40 & 3295369 & 57 & -1.90 & Yes & 4.1 & Right & 0.69 & EU.SAFTA & Embassy-Prague \\
\hline Indonesia & -318.02 & 41 & 13944167 & 43 & -1.62 & Yes & 12.3 & Left & -0.91 & & Embassy-Jakarta \\
\hline Turkey & -420.31 & 42 & 12327366 & 45 & 2.03 & Yes & 4.1 & Right & 0.04 & EU-SAFTA & Embassy-Ankara \\
\hline Austria & -451.47 & 43 & 7194403 & 51 & -1.90 & Yes & 4.1 & Right & 1.76 & EU-SA FTA & Embassy-Vienna \\
\hline Sweden & -453.88 & 44 & 40728223 & 29 & -0.49 & Yes & 4.1 & Right & 1.85 & EUSAFTA & Embassy-stockholm \\
\hline Saudi Arabie & -461.27 & 45 & 7259523 & 50 & -1.98 & Yes & 4 & Right & 0.20 & & Embassy-Riyach \\
\hline Cameroon & -491.36 & 46 & 18151552 & 40 & 1.24 & Yes & 15.5 & Right & -1.00 & African Union & High commission-Yaounde \\
\hline Poland & -583.92 & 47 & 3519189 & 56 & .3 .38 & Yes & 4.1 & Right & 0.51 & Afican Union & Embassy-Warsaw \\
\hline India & -768.23 & 48 & 74725492 & 24 & .0 .54 & Yes & 24.8 & Left & .0 .09 & & High commrission-New Delhi \\
\hline Greece & -854.50 & 49 & 19722845 & 38 & -1.01 & Yes & 4.1 & Right & 0.75 & EU-SAFTA & Embassy-Athens \\
\hline Madagascar & -919.08 & 50 & 25254488 & 36 & 1.90 & Yes & 11.1 & Right & .0 .30 & $S A D C$, African Union & Repoffice-Antananaivo \\
\hline New Zealand & -973.04 & 51 & 120232708 & 19 & 1.11 & Yes & 4.6 & Left & 1.93 & & \\
\hline Mexico & -978.61 & 52 & 25603613 & 35 & -1.49 & Yes & 17.3 & Right & .026 & & Embassy-Mexico city \\
\hline United Arab Emirates & -1100.02 & 53 & 35568517 & 32 & 1.01 & Yes & 4 & Right & 0.85 & & $\begin{array}{l}\text { Consular general-Dubai, representative office-Abu } \\
\text { Chabl }\end{array}$ \\
\hline & & & & & & & & & & SACU-MERCOSUR PTA & \\
\hline $\begin{array}{l}\text { Brazil } \\
\text { Uganda }\end{array}$ & $\begin{array}{l}-1194.45 \\
.127076\end{array}$ & $\begin{array}{c}54 \\
55\end{array}$ & $\begin{array}{l}97152760 \\
32531761\end{array}$ & $\begin{array}{l}20 \\
33\end{array}$ & $\begin{array}{l}-0.68 \\
0.15\end{array}$ & $\begin{array}{l}\text { Yes } \\
\text { Yes }\end{array}$ & $\begin{array}{l}18.1 \\
6.7\end{array}$ & $\begin{array}{l}\text { Right } \\
\text { left }\end{array}$ & $\begin{array}{l}-021 \\
.079\end{array}$ & $\begin{array}{l}(2004) \\
\text { Afican Unian }\end{array}$ & Embassy-Brasilia,Consulate-Sao Paulo \\
\hline Uganda & -1270.76 & 55 & 32531761 & 33 & 0.15 & Yes & 6.7 & Left & -0.79 & Afican Union & Embassy-Kampala \\
\hline Mauritus & -1379.06 & 56 & 84357997 & 22 & 2.86 & Yes & 5.1 & Left & 0.84 & SADC, African Union & High commission-Port: Louls \\
\hline Ghara & -1709.69 & 57 & 57747793 & 26 & 2.38 & Yes & 32.1 & Right & -0.16 & Afican Union & High commission-Acrar \\
\hline Angola & -1992.32 & 58 & 81032818 & 23 & 2.32 & Yes & 3.4 & Right & -1.33 & SADC, Arican Union & Embassy-Luanda \\
\hline France & .2337 .73 & 59 & 131099366 & 18 & -1.09 & Yes & 4.1 & Right & 1.33 & EU-SAFTA & Embassy-Paris \\
\hline Russian Federation & 4599.92 & 60 & 975638 & 68 & -3.17 & No & 11 & Right & -0.70 & & Embassy-Moscow \\
\hline Singapore & .7274 .77 & 61 & 253187709 & 13 & 1.51 & Yes & 0 & Left & 1.82 & & High comission-Singapore \\
\hline Nigeria & .7799 .12 & 62 & 36643414 & 31 & 0.56 & Yes & 8.6 & Right & -144 & Afican Union & High commission-Abuja,rep office-Lagos \\
\hline Spain & 8620.68 & 63 & 245892873 & 14 & -0.17 & Yes & 4.1 & Right & 1.12 & EU-SAFTA & Embassy-Madind, General consulate- Bllbao \\
\hline Zimbabve & .9122 .60 & 64 & 921670329 & 6 & 4.43 & Yes & 13.6 & Left & .153 & SADC, Arican Union & High commission:Zimbabwe \\
\hline Hong Kong-Chira & -15803.17 & 65 & 154657200 & 15 & 0.38 & Yes & 0 & Left & 1.42 & & Consulate-Hongkong \\
\hline & & & & & & & & & & MOU to solve issues of mutual & \\
\hline Chile & -49071.66 & 66 & 4796991 & 54 & -1.30 & Yes & 5.5 & Right & 1.16 & interest & Embassy-Santago \\
\hline Germany & -68691.42 & 67 & 3655635646 & 1 & 1.02 & Yes & 4.1 & Right & 1.66 & EU-SAFTA & Embassy-Berlin \\
\hline & & & & & & & & & & $\begin{array}{l}\text { Chairs the Cairns group, Indian } \\
\text { Ocean Rim Association for }\end{array}$ & \\
\hline Australia & -107194.16 & 68 & 1708347537 & 5 & 1.65 & Yes & 6.2 & Left & 1.82 & Regonal Co-ope ration & High commrission-Canberra \\
\hline United Kingdom & -141325.97 & 69 & 2546662594 & 3 & 2.39 & Yes & 4.1 & Left & 1.71 & $\begin{array}{l}\text { EU-SA FTA } \\
\text { US-SACUFT Nernfitions }\end{array}$ & $\begin{array}{l}\text { High commission-London } \\
\text { Fingssy-Washinton Geral }\end{array}$ \\
\hline United States & -148427.23 & 70 & 2639014307 & 2 & 0.32 & Yes & 3.1 & Right. & 1.58 & $\begin{array}{l}\text { AS-SACU FAA Negotatitions, } \\
\text { AGOA,GSP }\end{array}$ & 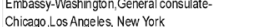 \\
\hline Japan & -378956.16 & 71 & 2464901564 & 4 & -0.40 & Yes & 0 & Right & 1.39 & & 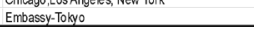 \\
\hline
\end{tabular}

\section{5}

\section{Conclusion}

This study applies an "augmented" gravity model to South Africa's annual bilateral exports of motor vehicles, parts and accessories (SIC 381-383) to 71 of its trading partners over the period 1994 to 2004. A static panel data model is utilised to estimate the coefficients. A number of results emerge from the study.

First, certain characteristics of the trading partners enhance South Africa's exports of motor vehicles and parts and accessories: GDP, government effectiveness, regulatory quality, English language, membership to EU, Africa, NAFTA, Asia, and MERCOSUR (South America) as well as whether drivers in a country keep left or not.

Second, geographical distance, import tariffs levied on motor equipment and the fact that a country is located in the Middle East tend to inhibit the exports of motor vehicles and parts and accessories. The negative effect of distance implies that high transport costs inhibit South Africa exports of motor vehicles and parts and accessories. This is not surprising given the fact that the automotive export products are bulky.

Third, there are country-specific fixed effects, which tend to inhibit South Africa's exports. There is therefore a need to conduct a survey to determine these factors.

Fourth, the positive time-specific effects after 2002 show that the MIDP has been effective in enhancing the performance of the automotive industry exports. The question that needs to be addressed is what happens after the expiry of the MIDP in 2012?

Fifth, the gravity model shows that there are a number of countries where there is export potential that South Africa can exploit. However, there are some difficulties that exporters may face in exploiting these export destinations (Tables 6a and 6b). These include, among others, very high import tariffs, lack of South Africa's diplomatic mission in the trading partner, country not being a member of the WTO, lack of trade agreement with the country. There is therefore a need for the Department of Trade and Industry (DTI) to work on these issues with a view to making it easy for NAAMSA members to export. 
Finally, despite the appealing results, the gravity model results and trade potentials should be interpreted with caution. The gravity model is very sensitive to the sample selected and hence the export potential may change depending on the model specification.

\section{References}

1 ANDERSON, J.E. (1979) "A theoretical foundation for the gravity equation", American Economic Review, 69: 106-16.

2 ANDERSON, J.E. \& VAN WINCOOP, E. (2003) "Gravity with gravitas: A solution to the border puzzle", American Economic Review, 93(1): 170192.

3 BARNES, J.; KAPLINKSY, R. \& MORRIS, M. (2004) "Industrial policy in developing countries", Competition and Change, 8(2): 153-172.

4 BERGSTRAND, J.H. (1985) "The gravity equation in international trade: Some microeconomic foundations and empirical evidence", The Review of Economics and Statistics, 67: 474-481.

5 BERGSTRAND, J.H. (1989) "The generalised gravity equation, monopolistic competition, and the factor-proportions theory in international trade", The Review of Economics and Statistics, 71(1): 143-153.

6 BLACK, A. (1994) An Industrial Strategy for the Motor Vehicle and Component Sector, University of Cape Town Press: Cape Town.

7 BLACK, A. \& MITCHELL, S. (2002) "Policy in the South African motor industry: Goals, incentives and outcomes", Paper presented at the Annual Forum of the Trade and Industrial Policy Strategies, 2002.

8 BLACK, A. (2003) "The export 'success' of the motor industry development programme and the implications for trade and industrial policy" [Online] Available from http://www.commerce.uct. ac.za/economics/postgrad/masters/trp/research/ black export success.pdf, accessed 30 January 2005.

9 CHENERY, H. \& SRINIVASEN, T. (1988) Handbook of Development Economics, Vol.1 Industrialisation and Trade, Elsevier Science Publishers B.V.: Amsterdam, The Netherlands.

10 CHENG, I. \& WALL, H.J. (2005) “Controlling for heterogeneity in gravity models of trade and integration", Federal Reserve Bank of St.Louis Review, 87(1): 49-63.

11 DEARDORFF, A. (1998) "Determinants of bilateral trade: Does gravity work in a frictionless world?" In Jeffrey Frankel (ed.) The Regionalization of the World Economy, University of Chicago Press: Chicago: pp 7-28.

12 DEPARTMENT OF TRADE \& INDUSTRY. (2004) "Motor industry development plan" Online, Available http://www.thedti.gov.za/publications/ automotive04.htm Accessed 12 December 2004.

13 FLATTERS, F. (2005) "The economics of MIDP and the South African motor industry", Paper Presented at TIPS/NEDLAC South Africa Trade and Poverty Programme (SATPP) Policy dialogue Workshop, Johannesburg, November 2005.

14 FRANSE, R. (2006) "The response of an original equipment manufacturer to the motor industry development programme: A case study", Unpublished Masters Thesis, Rhodes University.

15 GROSSMAN, G. (1998) “Comment”, In Frankel (ed.) The Regionalisation of the World Economy The University of Chicago Press: Chicago and London.

16 INTERNATIONAL TRADE CENTRE (2003) "TradeSim: A gravity model for the calculation of trade potentials for developing countries and economies in transition”, Technical Report, UNCTAD-WTO.

17 LEAMER, E. \& STERN, R. (1970) Quantitative International Economics. Allyn and Bacon: Boston.

18 LINNEMANN, H. (1966) An Econometric Study of International Trade Flows, North-Holland: Amsterdam.

19 McCALLUM, J. (1995) "National borders matter: Canada-U.S. regional trade patterns", American Economic Review, 85(3): 615-623.

20 NATIONAL ASSOCIATION OF AUTOMOBILE MANUFACTURERS OF SOUTH AFRICA (NAAMSA). (2004) “Annual report 2004” [Online] Available: http://www.naamsa.co.za/reports, accessed 20 May 2005.

21 NATIONAL ASSOCIATION OF AUTOMOBILE MANUFACTURERS OF SOUTH AFRICA (NAAMSA). (2005) "Annual Report 2005" [Online] Available: http://www.naamsa.co.za/ reports, accessed n 20 April 2006.

22 OGULEDO, V.I. \& MACPHEE, C.R. (1994) "Gravity models: A reformulation and application to discriminatory trade arrangements", Applied Economics, 26: 107-120.

23 PöYHöNEN, P. (1963) "A tentative model for the volume of trade between countries", Weltwirtschaftliches Archiv, 90: 93-99.

24 TINBERGEN, J. (1962) Shaping the World Economy: Suggestions for an International Economic Policy, Twentieth Century Fund: New York. 